\title{
The contribution of genetic variation and infection to the pathogenesis of ANCA-associated systemic vasculitis
}

\author{
Lisa C Willcocks', Paul A Lyons', Andrew J Rees ${ }^{2,3}$ and Kenneth GC Smith*1
}

\begin{abstract}
The aetiology of anti-neutrophil cytoplasmic antibody (ANCA)-associated systemic vasculitis has not been well defined. Here we review two factors which may play a role in the pathogenesis of the disease: genetics and infection. In particular, we discuss the role of autoantibodies to LAMP-2, which may arise following infection with Gram-negative bacteria, and may contribute to the development of ANCA-associated systemic vasculitis in genetically susceptible individuals.
\end{abstract}

\section{Introduction}

Primary systemic vasculitis is characterised by inflammation and necrosis of blood vessel walls. The disease is broadly classified according to the size of the vessels involved, as proposed by the Chapel Hill Consensus Conference [1]. Further categorisation relies on clinical and histological findings, as well as the detection of autoantibodies. Three of the small vessel vasculitides Wegener's Granulomatosis (WG), microscopic polyangiitis (MPA) and Churg-Strauss syndrome (CSS) - are typified by vasculitic lesions with little or no immune complex deposition and by anti-neutrophil cytoplasmic antibodies (ANCA). These diseases are collectively known as ANCA-associated systemic vasculitis (AAV).

Many clinical features are common to all types of AAV, including nonspecific inflammatory symptoms such as malaise, fever, anaemia and weight loss. Multiple organ systems may be affected; for example, vasculitic lesions may manifest as a rash, arthralgia, pulmonary haemorrhage and necrotising glomerulonephritis. There are, however, phenotypic differences between types of AAV:

\footnotetext{
*Correspondence: kgcs2@cam.ac.uk

${ }^{1}$ Cambridge Institute for Medical Research and Department of Medicine, University of Cambridge School of Clinical Medicine, Addenbrooke's Hospital, Hills Road, Cambridge CB2 OXY, UK.

Full list of author information is available at the end of the article
}

WG characteristically has ear, nose and throat and/or respiratory involvement. Necrotising granulomas may cause sinusitis, nasal discharge, damage to the nasal septum, hearing loss and/or haemoptysis. CSS is associated with asthma and eosinophilia. MPA commonly affects the kidney without evidence of granulomas, upper respiratory tract involvement or asthma.

The association with ANCA also varies: 80 to $90 \%$ of individuals with WG and MPA are ANCA-positive, compared with $40 \%$ of patients with CSS. The sensitivity for ANCA in the diagnosis of WG and MPA is 81 to $85 \%$, whilst the specificity (if assayed by both immunoflourescence and ELISA) is 98\% [2]. The type of ANCA varies with AAV subtype; MPA is predominantly associated with perinuclear ANCA (p-ANCA) antibodies to the enzyme myeloperoxidase (MPO), whilst patients with WG are more likely to have cytoplasmic ANCA (c-ANCA) antibodies to proteinase 3 (PR3) [3]. Nonetheless, there is considerable overlap between the classification of WG and MPA [3,4].

AAV has a substantial morbidity and mortality; $15 \%$ of patients are dead within 1 year of diagnosis, and 35\% are dead within 5 years [4]. Although 1-year survival rates are similar for all types of AAV (82.7 to 85.5\%), survival at 5 years is worse in patients with MPA (45.1\%) compared with WG and CSS (75.9\% and 68.1\%, respectively) [4].

The cause of AAV is not clear, although both environmental factors and genetic susceptibility have been implicated. A number of genetic polymorphisms have been associated with AAV, and with WG in particular. This suggests that the genetic contribution to AAV is polygenic, as with other autoimmune diseases such as rheumatoid arthritis, systemic lupus erythematosus (SLE) and type 1 diabetes. In these diseases, genetic susceptibility is determined by relatively common variants that are found throughout the population, each of which contributes only modestly to disease risk. This has been termed the common disease, common variant hypothesis [5].

\section{Epidemiology}

The incidence of AAV across different populations is broadly similar at 12 to 18 per million of population per 
year. The type of vasculitis varies, however, with WG being more common in populations from Norway and the UK, and MPA more common in Spain and Japan $[6,7]$. The prevalence of WG in a predominantly Northern European Caucasian population from New Zealand was similar to that in the UK and Norway [8]. These population differences in the predominant type of AAV may reflect genetic differences and/or environmental factors.

Ethnic differences may influence both the type and incidence of AAV. Assessment of disease by ethnic distributions in US cohorts suggested WG is more prevalent in Caucasians than in African Americans [9]. In New Zealand in 2003, the 5-year incidence of WG was twice as high in individuals of European ancestry as in those of New Zealand Maori or Asian background, whereas Pacific Islanders had a rate approximately one-half that of New Zealand Maori or Asian [8]. Ethnicity may also be a risk factor for all types of AAV when environmental factors are controlled - in a French multi-ethnic population, AAV was twice as common in individuals of European, compared with non-European, ancestry [10], suggesting different degrees of genetic risk.

\section{Genetics}

More direct evidence for a genetic basis for WG comes from a recent familial aggregation study. This found a relative risk of 1.56 for first-degree relatives of patients with WG [11], which is similar to that seen in rheumatoid arthritis $[12,13]$ and suggests there are genetic risk factors for WG. In addition, case reports of familial clustering in AAV have reported polyarteritis nodosa and CSS occurring amongst relatives of patients with WG [14,15], suggesting common genetic risk factors may predispose to different types of vasculitis.

A number of candidate gene association studies have identified variants associated with an increased incidence of AAV. Most of the genes so far described encode proteins involved in the immune response (Table 1).

\section{Replicated genetic associations Major histocompatibility complex}

The human MHC region spans $3.6 \mathrm{Mb}$ containing more than 250 genes, more than one-half of which have immunological functions. Variants in MHC have been strongly associated with several autoimmune diseases, including type 1 diabetes [16] and SLE [17]. A number of small studies have suggested associations between WG and MHC loci, including HLA-B50 [18], HLA-DQw7 [19], HLA-DR3 [19], HLA-DR1 [20] and HLA-DR9 [18].

More significantly, a recent study revealed a strong association of WG with an allele encoding class II molecule DPB1*0401 (odds ratio (OR) $=3.91, P=1.51 \mathrm{x}$ $10^{-10}$ ). In addition, the extended haplotype DPB1*0401/
RXRB03 showed an even stronger association with WG (OR $=6.41, P=7.13 \times 10^{-17}$ ) [21], raising the possibility of additional susceptibility loci. A more recent study has replicated the association of the DPB1*0401 allele with WG. A single nucleotide polymorphism (SNP) 3' of HLA-DPB1 was most associated $\left(P=6.4 \times 10^{-8}\right)$, whilst another SNP in the vicinity of RING1 (which encodes a transcriptional repressor) also showed a significant WG association that was partly independent of the HLA$D P B 1$ effect [22]. The $H L A-D R 4$ allele was also associated with susceptibility to both AAV (in general) and WG (in a subset) in a study of 304 Dutch patients and 9,872 controls [23]. Between the four disease subsets (WG, MPA, CSS and renal-limited vasculitis), the HLA antigen distribution did not differ - except for DR8, which was more prevalent in patients with CSS than in the other three groups of AAV $(P<0.0001)$ [23].

Two studies have identified an association between susceptibility to CSS and HLA-DRB4, whilst HLA-DRB3 was associated with protection against the disease $[24,25]$. As WG and CSS are thus associated with different HLA genotypes, it has been argued that they may in fact be separate disease entities, and not closely related disease variants as previously thought [24].

\section{PRTN3 gene}

The genes encoding ANCA target antigens may play a role in the pathogenesis of AAV. PRTN3 encodes PR3, an intracellular serum protease against which ANCA are commonly directed in WG. PR3 is also expressed on the surface expression of neutrophils. The expression pattern is bimodal in individuals; the proportion of neutrophils that are high or low expressers remains constant over time, and is unaffected by age or gender [26]. This surface expression pattern correlates much more closely in monozygotic twins $(r=0.99)$ than dizygotic twins $(r=0.06)$, suggesting it is genetically determined [27]. One study found that the distribution of membranebound PR3 in 37 AAV patients (16 with WG, 21 with MPA) was significantly skewed toward the membranebound PR3 high phenotype when compared with 126 healthy controls; $85 \%$ of AAV patients expressed high levels of membrane-bound PR3 versus 55\% in healthy subjects [26]. This finding was replicated in a second study, which also showed that in 89 WG patients an elevated level of membrane-bound PR3 expression was significantly associated with an increased relapse rate $(P=0.011)$, but not with the disease extent or particular manifestations at diagnosis [28]. Interestingly, a study in 17 sibling pairs matched at 34 HLA antigens showed a high concordance in neutrophil membrane-bound PR3 expression $(r=0.67, P<0.05)$, approaching that seen in monozygotic twins [29]. The authors propose that the percentage of membrane PR3-positive neutrophils is 
Table 1. Positive genetic association studies in anti-neutrophil cytoplasmic antibody-associated systemic vasculitis

\begin{tabular}{|c|c|c|c|c|c|c|}
\hline Gene & Population origin & Cases & Controls & Odds ratio & $P$ value & Reference \\
\hline HLADPB1*0401 & Germany & $150 W G$ & 100 & 3.9 & $1.5 \times 10^{-10}$ & {$[21]$} \\
\hline HLA DPB 1*0401 & Germany & $282 W G$ & 380 & & $6.4 \times 10^{-8}$ & {$[22]$} \\
\hline HLAB50 & $\begin{array}{l}\text { North America, } \\
\text { Caucasian }\end{array}$ & $83 W G$ & 4,039 & $4.89^{\mathrm{a}}$ & $<0.0001$ & {$[18]$} \\
\hline HLADR9 & $\begin{array}{l}\text { North America, } \\
\text { Caucasian }\end{array}$ & $76 W G$ & 4,039 & $4.00^{\mathrm{a}}$ & 0.005 & [18] \\
\hline HLADQW7 & UK & $34 \mathrm{WG}, 25 \mathrm{MPA}$ & 1,103 & 2.9 & $<0.0025$ & {$[19]$} \\
\hline HLADR3 & UK & $34 \mathrm{WG}, 25 \mathrm{MPA}$ & 1,103 & 0.31 & $<0.01$ & {$[19]$} \\
\hline HLADR1 & UK & $27 W G$ & 500 to $2,000 ?$ & 2.3 & 0.0001 & {$[20]$} \\
\hline HLADR4 & The Netherlands & 304 (241 WG, 30 MPA, 12 CSS, 21 RLV) & 9,872 & 1.7 & $<0.0001$ & [23] \\
\hline HLADR6 & The Netherlands & 304 (241 WG, 30 MPA, 12 CSS, 21 RLV) & 9,872 & 0.3 & $<0.0001$ & {$[23]$} \\
\hline HLA DRBA & Italy & 48 CSS & 350 & 2.49 & $2.3 \times 10^{-4}$ & {$[25]$} \\
\hline HLA DRB3 & Italy & 48 CSS & 350 & 0.54 & 0.028 & {$[25]$} \\
\hline HLA DRB4 & Germany & 102 CSS & 341 & 1.87 & $2 \times 10^{-4}$ & {$[24]$} \\
\hline HLA DRB3 & Germany & 102 CSS & 341 & 0.61 & 0.004 & {$[24]$} \\
\hline PTPN22-620W & Germany & 199 WG & 399 & 1.8 & 0.002 & {$[41]$} \\
\hline PTPN22-620W & UK & 641 (WG, MPA and CSS) & 9,115 & 1.4 & $1.4 \times 10^{-4}$ & {$[43]$} \\
\hline IL-2RA rs41295061 & UK & 675 (WG, MPA and CSS) & 8,936 & 0.77 & 0.012 & {$[42]$} \\
\hline CTLA4-318T & Sweden & $32 W G$ & 122 & 3.26 & $<0.05$ & {$[46]$} \\
\hline CTLA4+49G & The Netherlands & $50 \mathrm{WG}, 24 \mathrm{MPA}, 7 \mathrm{CSS}, 21 \mathrm{RLV}$ & 188 & 1.32 & 0.01 & {$[48]$} \\
\hline CTLA4 rs3087243 & UK & 641 (WG, MPA and CSS) & 9,115 & 1.19 & $6.4 \times 10^{-3}$ & {$[43]$} \\
\hline PRTN3 -564G & Germany & $66 \mathrm{WG}$ & 106 & 0.5 & $<0.01$ & {$[30]$} \\
\hline AAT Zallele & Italy & 33 WG, 28 MPA, 23 RLV & 200 & $3.7^{\mathrm{a}}$ & 0.022 & {$[36]$} \\
\hline AAT Zallele & Austria & 29 WG, 2 MPA, 1 RLV & 868 & 13.2 & $<0.0001$ & {$[37]$} \\
\hline AAT Zallele & Germany & $79 W G$ & 752 & $3.8^{\mathrm{a}}$ & $<0.0001$ & {$[35]$} \\
\hline AAT Zallele & Sweden & 88 (66 WG) & $?$ & 6.0 & $<0.0001$ & {$[95]$} \\
\hline AATZ allele & Scandinavia & $44 W G$ & $?$ & $?$ & $<0.001$ & [34] \\
\hline $\mathrm{C} 3 \mathrm{~F}$ & Sweden & 34 WG, $33 \mathrm{MPA}$ & 101 & 0.52 & $<0.05$ & {$[58]$} \\
\hline CD18 Ava II & Germany & 31 MPO positive & 120 & 2.56 & $<0.005$ & {$[57]$} \\
\hline IL-10 microsatellite & Sweden & $32 W G$ & 109 & 7.94 & $<0.0032$ & {$[51]$} \\
\hline $\begin{array}{l}\text { IL-10 (-1082) } \\
\text { AA genotype }\end{array}$ & Germany & $125 \mathrm{WG}, 36 \mathrm{MPA}$ & 153 & 0.30 & $<0.0001$ & {$[52]$} \\
\hline IL-10 haplotype & Germany & 103 CSS & 507 & 2.16 & 0.0003 & [53] \\
\hline $\begin{array}{l}\text { LILRA2 intron } 6 \\
\text { AA genotype }\end{array}$ & Japan & $50 \mathrm{MPA}$ & 284 & 2.52 & 0.049 & [54] \\
\hline CD226rs763361 & Germany & $642 W G$ & 1226 & 1.20 & 0.016 & {$[56]$} \\
\hline $\begin{array}{l}\text { FCGR2A R131 } \\
\text { RR genotype } \\
\text { with FCGR3A F158 FF }\end{array}$ & The Netherlands & 91 WG & 154 & 4.60 & 0.0092 & {$[64]$} \\
\hline $\begin{array}{l}\text { FCGR3B copy } \\
\text { number high }\end{array}$ & UK & 556 (WG, MPA and CSS) & 286 & & $1 \times 10^{-8}$ & {$[74]$} \\
\hline $\begin{array}{l}\text { FCGR3B copy } \\
\text { number low }\end{array}$ & UK & $80 W G$ & 190 & & 0.003 & [73] \\
\hline $\begin{array}{l}\text { FCGR3B copy } \\
\text { number low }\end{array}$ & UK & $76 \mathrm{MPA}$ & 190 & & 0.0003 & [73] \\
\hline $\begin{array}{l}\text { FCGR3B copy } \\
\text { number low }\end{array}$ & France & $84 W G$ & 181 & & 0.0001 & [73] \\
\hline
\end{tabular}

CSS, Churg-Strauss syndrome; MPA, microscopic polyangiitis; MPO, myeloperoxidase; RLV = renal-limited vasculitis; WG, Wegener's granulomatosis. ${ }^{a}$ No odds ratio given in the reference; values calculated using Graphpad prism, 2 × 2 chi-squared test. 
dictated by HLA antigens, but do not suggest a mechanism for this effect.

Eight SNPs have been identified in the promoter and exonic sequences of $P R T N 3$, and a polymorphism in the promoter region of $P R T N 3$ (A-564G), affecting a putative transcription factor binding site, was associated with WG when allele frequencies were compared in 66 cases and 106 controls [30]. This study also identified a strong association between a haplotype of two of these eight SNPs and WG $\left(P<10^{-5}\right)$. It has not yet been shown whether these polymorphisms affect PR3 expression.

Expression of membrane PR3 on neutrophils is therefore likely to be genetically determined, and individuals with high levels of expression are at increased risk of AAV. The genetic polymorphisms that cause this variation in expression have not been fully elucidated.

\section{$a_{1}$-Antitrypsin}

PR3 is released when activated neutrophils degranulate, and directly damages endothelial cells - in vitro, the enzyme causes detachment and cytolysis of endothelial cells. The cationic enzyme also binds covalently to the endothelium, where it can bind ANCA and thus trigger antibody-dependent cytotoxicity [31]. $\alpha_{1}$-Antitrypsin is the major inhibitor of PR3 activity, and is thought to limit the damage done to local tissues. The gene encoding $\alpha_{1}$-antitrypsin $(A A T)$ is highly polymorphic, and several of the polymorphisms, including the $\mathrm{Z}$ and $\mathrm{S}$ alleles, reduce the function of the protein. The decreased function of $\alpha_{1}$-antitrypsin may result in persistence of PR3 in inflammatory tissue for longer, which may in turn result in the generation of ANCA.

Several groups have found an association of the presence of $\mathrm{Z}$ and $\mathrm{S}$ alleles with cANCA-positive and pANCApositive vasculitis, respectively [32], anti-PR3 antibodies [33], WG [34,35] or all AAV [36,37]. Neither anti-PR3 antibodies nor clinical features of WG were detected in $191 \alpha_{1}$-antitrypsin $\mathrm{Z}$ homozygotes [38], indicating that the deficiency contributes to, but is not the sole genetic determinant of, risk of AAV.

\section{PTPN22 gene}

PTPN22 encodes protein tyrosine phosphatase nonreceptor type 22 , an enzyme expressed predominantly by lymphocytes. The 620W (rs2476601) allelic variant of PTPN22 is associated with several autoimmune disorders, including type 1 diabetes mellitus, SLE and rheumatoid arthritis [39]. The associated allele appears to influence thresholds for T-cell receptor signalling, but the precise mechanisms for these associations remain unclear. In general, the PTPN22 620W allele has been implicated in autoimmune disorders that have a prominent humoral component, suggesting that PTPN22 activity in B cells may be important [40].
A study of 199 WG patients found an increase in the PTPN22 620W allele with an OR of 1.75 (95\% confidence interval $(\mathrm{CI})=1.21$ to $2.48, P=0.002)$ [41]. We genotyped this SNP in 641 AAV cases derived from four UK sources, including 205 patients with WG and 74 patients with MPA (further details of these sample collections are given in [42]). We found an association of all AAV with the minor allele $\left(P=1 \times 10^{-4}\right.$, OR $=1.4 ; 95 \%$ CI 1.18 to 1.67$)$, as well as an association with both WG and MPA when a subset of these patients with these diagnoses were analysed independently (WG, $P=6.0 \times 10^{-11}$, OR $=2.0$; MPA, $P=4.1 \times 10^{-6}$, OR $=2.55$ ) [43]. Thus, this SNP is likely to contribute to the risk of AAV, as well as other autoantibody-associated autoimmune diseases.

\section{Cytotoxic T-lymphocyte antigen 4}

CTLA4 (cytotoxic T-lymphocyte antigen 4) is mainly expressed on $\mathrm{CD}^{+} \mathrm{T}$ cells. When bound to its ligands (CD80 and CD86 on B cells and dendritic cells), CTLA4 inhibits T-cell function. Increased expression of CTLA4 is seen in WG [44]. Polymorphisms in CTLA4 have been associated with a number of autoimmune diseases [45]. Heterozygosity for a SNP in the promoter region of CTLA4 has been linked to WG [46], and this SNP has been shown to affect protein expression [47]. A small study of CTLA4 SNPs did not find a significant association with this promoter polymorphism in a study of 102 patients and 188 controls, but found that a different SNP $(+49 G)$ was associated with AAV when individuals either heterozygote or homozygote for the G allele were compared [48]. We found an association of another autoimmune disease-associated SNP in CTLA4 (rs3087243) with AAV in the 641 cases and 9,115 controls described above $\left(P=6.4 \times 10^{-3}\right.$, OR $=1.19 ; 95 \% \mathrm{CI}=1.05$ to 1.34) [43]. The association of CTLA polymorphisms with other autoimmune diseases strengthens the case that SNPs in this gene to contribute to AAV susceptibility.

\section{Unreplicated associations \\ High-affinity IL-2 receptor}

The cytokine IL-2 drives the division and survival of effector T cells, and is also important in regulatory T-cell homeostasis. Activated $\mathrm{T}$ cells and regulatory $\mathrm{T}$ cells express the high-affinity IL-2 receptor (IL-2RA or CD25). The receptor is also expressed on other immune cells including activated B cells, dendritic cells and activated monocytes, where its physiological role is less well defined. Polymorphisms in the $I L-2 R A$ locus have been associated with type 1 diabetes, multiple sclerosis and Graves' disease [49]. When rs41295061, one of the SNPs associated with type 1 diabetes, was compared in 744 AAV cases (comprising WG, MPA and CSS) and 9,115 controls, the minor allele frequency was increased in AAV cases $(P=0.012$, OR $=0.77 ; 95 \% \mathrm{CI}=0.63$ to 0.95$)$ 
[42]. Furthermore, soluble IL-2RA concentrations in the serum of AAV patients were higher than in controls, and disease activity as assessed by the Birmingham Vasculitis Activity Score also showed a positive correlation with soluble IL-2RA concentrations [42], as has previously been reported in WG patients [50]. The differences in soluble IL-2RA provide a physiological correlate of genetic variation that may contribute to the AAV risk.

\section{Interleukin-10}

IL-10 is an anti-inflammatory cytokine produced primarily by monocytes and to a lesser extent by lymphocytes. This cytokine has pleiotropic effects on immunoregulation and inflammation. It downregulates the expression of Th1 cytokines, MHC class II antigens, and co-stimulatory molecules on macrophages. It also enhances B-cell survival, proliferation, and antibody production. A small study of 32 WG patients found an association with a polymorphism in $I L-10$ that has previously been associated with autoantibody production [51]. A larger study of $125 \mathrm{WG}$ cases and 153 controls also found a SNP in $I L-10$ was associated with WG [52], with homozygosity for the minor allele over-represented in the patients $(P=0.0021$; OR $=0.354 ; 95 \% \mathrm{CI}=0.183$ 0.684). Conversely, a study of 403 WG patients did not find an association with three SNPs in $I L-10$, although a haplotype was associated with ANCA-negative CSS [53]. Further studies are needed to clarify the role of polymorphisms in the gene encoding this anti-inflammatory cytokine.

\section{Leukocyte immunoglobulin-like receptor A2}

LILRA2 is one member of the family of leukocyte immunoglobulin-like receptors. The leukocyte immunoglobulin-like receptors in subfamily A initiate stimulatory cascades, and LILRA2 is involved in the activation of granulocytes and macrophages. A SNP in LILRA2 (rs2241524 G>A) activates a cryptic splice acceptor site, resulting in a novel LILRA2 isoform. Homozygosity for the minor allele of SNP was associated with both SLE and MPA in a recent study [54], although only $50 \mathrm{MPA}$ patients were included.

\section{CD226 gene}

CD226 (DNAX accessory molecule 1) is an immunoglobulin superfamily adhesion molecule expressed on the surface of natural killer cells, platelets, monocytes and $\mathrm{T}$ cells. It binds CD155, which is found on epithelial cells, endothelial cells and antigen-presenting cells. CD226 appears to contribute to multiple innate and adaptive responses, including leukocyte migration, activation and expansion differentiation of CD8 T cells and CD4 T cells, and effector responses of $\mathrm{T}$ cells and natural killer cells [55]. The minor allele of a polymorphism in CD226, rs763361, which encodes a glycine to serine substitution at position 307, was associated with disease in two German WG cohorts ( $\mathrm{OR}=1.23, P=0.0031)$, but not in a UK cohort [56]. When we studied this polymorphism in 641 UK cases and 9,115 controls, we did not find an association with AAV, or with WG in a subset analysis [43]. This suggests that the disease risk associated with the minor allele of this polymorphism is much smaller in UK Caucasians than in German Caucasians.

\section{Associations with other single nucleotide polymorphisms}

A SNP in the gene encoding integrin CD18, a leucocyte adhesion molecule, has been associated with MPO ANCA-positive AAV [57], and another in the gene for complement component $\mathrm{C} 3$ has been associated with a combination of WG and MPA [58]. These studies are too small to be conclusive without replication.

Several groups have looked for an association between AAV and polymorphisms in TNF genes (encoding the proinflammatory cytokines TNF $\alpha$ and TNF $\beta$ ), and none have shown statistically significant differences $[59,60]$.

\section{Fcy receptors}

The low-affinity $\mathrm{Fc} \gamma$ receptors ( $\mathrm{Fc} \gamma \mathrm{Rs}$ ) bind the $\mathrm{Fc}$ portion of IgG and mediate the effects of IgG immune complexes on leucocytes, resulting in immune responses that include recruitment to inflammatory lesions, phagocytosis, antibody-dependent cellular cytotoxicity, release of inflammatory mediators and antibody production. The activation of primed neutrophils by ANCA requires FcyRs. Human neutrophils constitutively express the low-affinity activatory Fc $\gamma$ Rs, FcyRIIa (CD32) and FcyRIIIb (CD16), and both of these receptors have been shown to play a role in ANCA-induced neutrophil activation [61]. ANCA crosslink MPO and PR3 with these FcyRs to trigger intracellular signalling, which results in superoxide production, proinflammatory cytokine release and degranulation [31]. Both FCGR2A and $F C G R 3 B$ have functionally significant polymorphisms.

\section{Fcy receptor Ila}

FcyRIIa is a low-affinity, activatory FcyR expressed on monocytes, macrophages, platelets and activated dendritic cells as well as neutrophils. A polymorphism in FCGR2A results in a histidine to arginine substitution at amino acid position 131, altering receptor affinity and specificity for IgG subtypes - Fc $\gamma$ RIIa-H/131 binds IgG ${ }_{2}$ and $\mathrm{IgG}_{3}$ with increased avidity compared with the FcyRIIa-R131 homozygous genotype. In acute AAV, IgG predominates [62] and sera with higher $\operatorname{IgG}_{3}$ ANCA levels can preferentially activate neutrophils [63]. The FcyRIIa-R131 homozygous genotype, in combination with homozygosity for an allelic form of FcyRIIIa, was over-represented in Dutch patients with WG, and was 
also associated with increased disease relapse rates [64]. Individuals with the Fc $\gamma$ RIIa-R131 homozygous genotype have a reduced ability to phagocytose Staphlococcus aureus, which provokes an $\mathrm{IgG}_{2}$ antibody response [65]. Chronic nasal carriage of $S$. aureus has been associated with higher relapse rates in patients with WG [66], and thus the FcyRIIa-R131 homozygous genotype may predispose to WG relapse by reducing clearance of the bacterium. In a British study, however, no significant association was found between FcyRIIa genotype and ANCA-positive vasculitis or nephritis in 107 patients and 100 controls [67], although this study was powered to detect a minimum OR of 2.48, and smaller effect sizes cannot be excluded.

\section{Fcy receptor IIIb}

FcyRIIIb is a low-affinity, glycosylphosphatidylinositollinked Fc $\gamma R$ expressed only on human neutrophils. The receptor is activatory, and is thought to signal through association with complement receptor 3, FcyRIIa, or lipid rafts. FcyRIIIb can also be released from the surface of neutrophils upon activation. FCGR3B has two polymorphic forms, which differ by five nucleotides $(141,147$, 227 , 277, and 349) within exon 3, resulting in a fouramino-acid substitution in its membrane-distal immunoglobulin-like extracellular domain. This gives rise to two isoforms termed F $\gamma$ RIIIb-HNA1a and FcyRIIIb-HNA1b (previously known as NA1 and NA2, respectively), which have different IgG subtype affinities. FcyRIIIb-HNA1a has a higher affinity for $\operatorname{IgG}_{3}$, so might be expected to be associated with AAV. ANCA responses are greater in neutrophils from FcyRIIIb-HNA1a donors [68], and one study has shown a nonsignificant trend to an association of FCGR3B HNA1a with AAV [68]. However, FCGR3B has recently been shown to be present at variable copy number (see below), and these association studies need to be reinterpreted in the light of analysis of CNV.

\section{Copy number variation}

Copy number variation has been defined as a DNA segment that is $1 \mathrm{~kb}$ or larger and is present at variable copy numbers in comparison with a reference genome. As much as $5 \%$ of the human genome may lie within copy number variable regions [69]. The implications of such widespread genetic copy number variation on phenotypic variation are as yet uncertain, but some copy number variants clearly have a functional effect. For example, the copy number of CCL3LI has been associated with susceptibility to SLE [70], rheumatoid arthritis [71] and type 1 diabetes [71]. SLE has also been associated with variable copy number in the genes encoding complement component C4 [72], as well as in FCGR3B [73,74]. In vitro studies have shown that the FCGR3B copy number correlates with protein expression, with neutrophil uptake of and adherence to immune complexes, and with soluble serum Fc $\gamma$ RIIIb [74].

There is controversy regarding the association of FCGR3B copy number with AAV: Fanciulli and colleagues showed an association with low copy number in two WG cohorts of 80 and 84 patients, and in an MPA cohort of 76 patients [73]; whilst Willcocks and colleagues compared 556 patients with AAV from three different cohorts with 286 controls, and found in all three cohorts that AAV was associated with high FCGR3B copy number [74]. Copy number assays, however, often produce results that are continuously distributed across the population, rather than falling into discrete bins associated with copy numbers [75]. Difficulties in copy number assignation may therefore underlie these conflicting results. The association of the FCGR3B copy number with AAV needs to be reassessed now a more reliable copy number assay has been described [76].

Thus, although in vitro data implicate the Fc $\gamma$ Rs in mediating the actions of ANCA on neutrophil activation, a definitive view on the contribution of genetic variation in the FCGR locus to AAV requires a study which takes into account both SNPs, CNV and their potential interactions.

\section{Summary of genetic evidence}

Many genetic factors have been implicated in the pathogenesis of AAV. The increased risk in family members with WG is comparable with that seen in rheumatoid arthritis, for which genetic risk factors have been well characterised. Indeed, the genes with variants most strongly associated with AAV, the MHC and PTPN22 genes, also have variants associated with other autoimmune diseases, including rheumatoid arthritis, type 1 diabetes and SLE $[39,45]$. This suggests that genetic risk factors common to other autoimmune diseases also apply to AAV. Different variants within each gene may be associated with different polymorphisms for example, SLE associates with IL-2RA SNP rs11594656, while AAV is associated with rs41295061 [42]. Table 1 summarises results from positive genetic association studies performed to date. Most of these studies are either composed solely of patients with WG, or include a majority of patients with this type of AAV. It is not yet clear whether this is because the genetic contribution to WG is greater than that seen in the other types of AAV or whether this simply reflects the case mix of AAV in Northern European countries, where most of these studies have been performed. Larger cohorts need to be studied to allow subset analysis of the different types of AAV.

Several common autoimmune diseases have been the subject of genome-wide association studies, in which hundreds of thousands of SNPs throughout the genome 
are compared in cases and controls. These studies have identified new associations with variants in genes not previously known to be involved in pathogenesis; for example, in inflammatory bowel disease, the genes involved in the autophagy pathway [77]. Such associations identify new approaches for diagnosis and treatment, and a genome-wide study of AAV may be similarly enlightening.

\section{Environmental triggers and anti-neutrophil cytoplasmic antibody-associated systemic vasculitis}

The environmental agents that trigger the onset of AAV in genetically susceptible individuals remain elusive in the majority of patients. Epidemiological evidence suggests that the AAV is more common in people chronically exposed to a wide variety of environmental toxins, including pesticide, livestock, high solvent exposure, asbestos, hydrocarbon fumes and silica (reviewed in [78]). Evidence for causality is strongest for silica: exposed patients typically have the clinical syndrome of MPA and have ANCA that include specificity for MPO rather than for PR3 [79]. The mechanisms are unknown but could relate to the chronic proinflammatory effects of silica on macrophages and the consequent adjuvant effect of adaptive immune responses [80].

\section{Drugs}

The evidence that therapeutic drugs can induce AAV is more convincing. As many as one-half of patients treated with the anti-thyroid drug propylthiouracil may develop positive ANCA and anti-MPO assays, although far fewer develop overt vasculitis [81]. AAV has been reported after treatment with hydralazine for hypertension [82] and after penicillamine therapy for rheumatic disease [83], in both cases with pANCA-associated focal necrotising glomerulonephritis.

\section{Infections}

As only a small fraction of those presenting with AAV are exposed to these chemical triggers, other environmental agents must be involved, and these are commonly assumed to be infections, a view re-enforced by increasing evidence that bacterial infections are the initial event that breaks tolerance, resulting in autoimmunity in other contexts. Attempts to use data on the seasonal incidence of AAV to support a role for infection have been unhelpful - some studies have suggested that the incidence of WG is higher in the winter, when infection rates are higher, but other studies have not confirmed this suggestion (reviewed in [78]). Nonetheless, nearly two-thirds of patients presenting with WG are nasal carriers of $S$. aureus (significantly higher incidence than the general population) and nasal colonisation with $S$. aureus greatly increases the risk of disease relapse (relative risk 7.2), suggesting direct involvement [66]. Furthermore, in a randomised controlled trial, prophylactic treatment with co-trimoxazole reduced relapse rates by $60 \%$ [84]. ANCA positivity has been reported in patients with bacterial endocarditis, some of whom develop features of vasculitis [85]. In two of these, $S$. aureus was the causative organism [86,87], which may again point to a link between this species and AAV.

Molecular mimicry between pathogen and host proteins is often proposed as an explanation for the association between infection and autoimmunity [88]. This occurs when exposure to foreign proteins provokes synthesis of antibodies that cross-react with host proteins due to sequence or structural similarities. The resulting autoantibodies then cause disease. In an era of database searches, however, it is remarkably simple to find sequence homologies over eight to 10 amino acids that might be contained in a B-cell epitope. Consequently, claims for molecular mimicry need to be judged against stringent criteria before they can be accepted [89].

The evidence for $S$. aureus being a molecular mimic does not meet these standards: there are no known homologies between $S$. aureus proteins and the common ANCA targets MPO, PR3 and the more recently described LAMP-2 [90]; and similarly there are no suggestions that ANCA bind directly to S. aureus. No homologies have been identified between $S$. aureus proteins and the common ANCA targets, and no evidence has been published suggesting that ANCA themselves bind to $S$. aureus proteins. Accordingly there is no evidence that $S$. aureus is a conventional molecular mimic.

Pendergraft and colleagues suggested a more complex form of molecular mimicry to link $S$. aureus with anti-PR3 antibodies [91]. They noted that a proportion of patients with AAV and anti-PR3 antibodies also had circulating antibodies that recognised the complementary PR3 sequence - i.e. the protein that would result from transcription of the antisense strand of the PR3 gene. When they immunized mice with complementary PR3, antibodies developed to both complementary PR3 and subsequently to PR3, thus in mice at least, anti-PR3 and anti- complementary PR3 antibodies are idiotypes for each other [91]. Intriguingly, there is a weak homology between complementary PR3 and S. aureus proteins, and Pendergraft et al. suggested exposure to $S$. aureus induced anti-complementary PR3 antibodies that in turn induced anti-PR3 antibodies and AAV. However, there is no evidence that anti-complementary PR3 antibodies cross-react with $S$. aureus. Furthermore, rodents immunised with $S$. aureus do not develop AAV [92] although, interestingly, immunisation with Escherichia coli used as a control in this study did induce AAV in a small proportion of animals. 


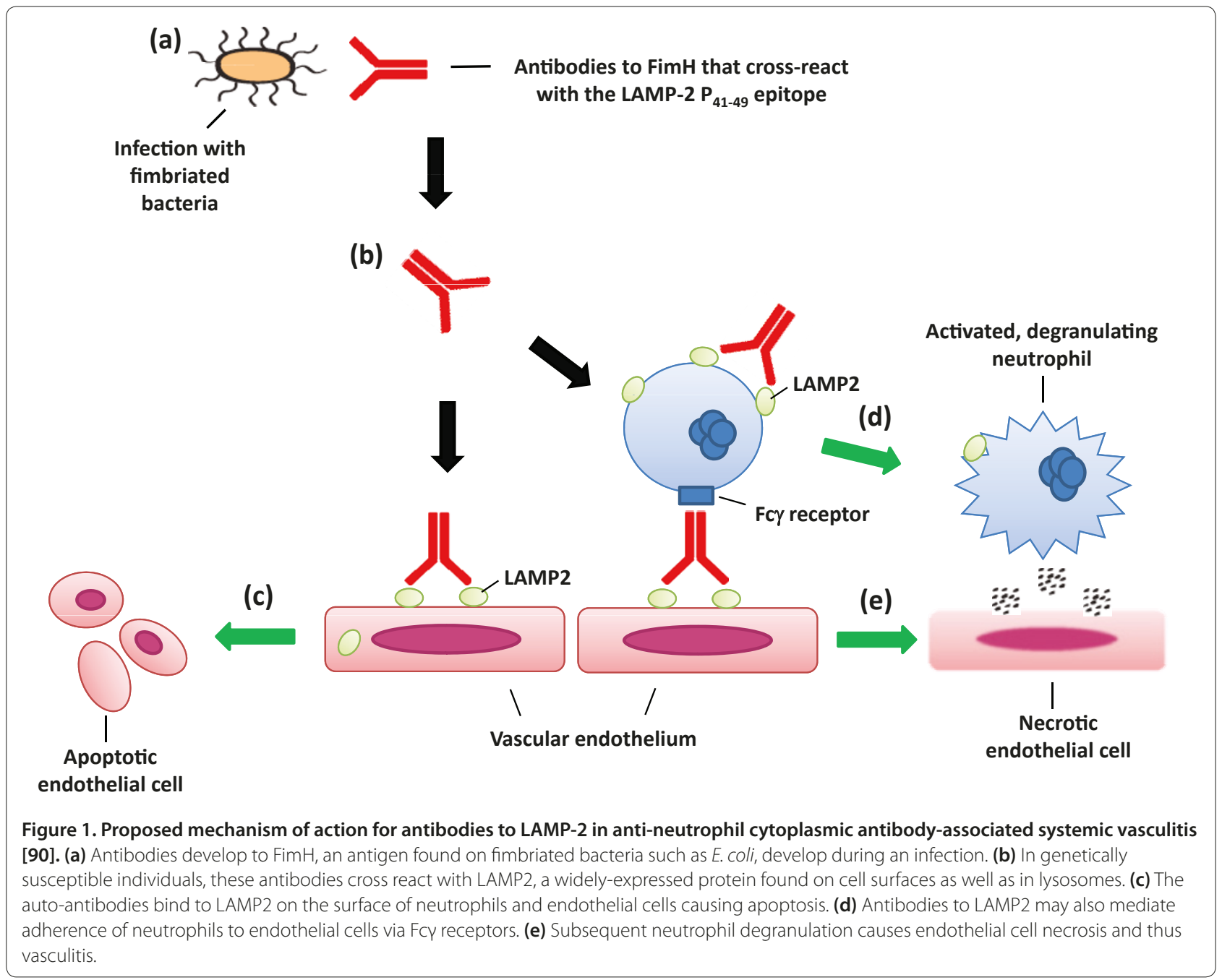

Until recently, attempts to link bacterial infection and AAV have been based on the idea that autoantibodies to the classical ANCA targets MPO and PR3 are the cause of AAV, but this is still the subject of considerable debate. These antibodies are closely associated with AAV and its activity, and there is compelling evidence that they can cause endothelial injury in vitro, and in vivo in the case of anti-MPO antibodies (reviewed in [31]). Kain and colleagues recently provided evidence that antibodies to LAMP-2 may have a pathogenic role in AAV, as well as providing evidence of molecular mimicry between LAMP-2 and the bacterial adhesion protein FimH [90].

LAMP-2 is a heavily glycosylated type 2 membrane protein found in high concentrations in lysosomes that also shuttles to the cell surface. Surface LAMP-2 has a role in cell adhesion, whilst intracellular LAMP-2 is critical for autophagy and presentation of intracellular antigens [93]. In neutrophils, LAMP-2 is found in the same vesicles as MPO and PR3 - consequently, autoantibodies to LAMP-2 give positive results in fluorescent
ANCA assays. LAMP-2 is also present on the cell membrane, however, and is immediately accessible to circulating autoantibodies [94].

Kain and colleagues found that autoantibodies to LAMP-2 were present in over $90 \%$ of a cohort of 84 patients with active AAV and pauci-immune focal necrotising glomerulonephritis, whereas autoantibodies to MPO and PR3 were each found in just under one-half of patients [90]. By contrast, assays to anti-LAMP-2 antibodies were negative when patients were in remission. A monoclonal antibody to human LAMP-2 activated neutrophils in vitro and induced apoptosis of human endothelial cells. Rats injected with polyclonal anti-LAMP-2 antibodies developed severe pauci-immune focal necrotising glomerulonephritis, confirming that the antibodies could be pathogenic.

Epitope mapping identified two dominant epitopes recognised by patients' autoantibodies, one of which, termed $\mathrm{P}_{31.39}$, was homologous (with eight out of nine amino acids identical) to a sequence in the mannose 
binding pocket of FimH, an adhesin expressed by Gramnegative bacteria. Patients' autoantibodies cross-reacted with FimH, and rats immunised with FimH developed anti-FimH antibodies that cross-reacted with human and rat LAMP-2. The immunised rats also developed AAV with pauci-immune focal necrotising glomerulonephritis. Kain and colleagues hypothesise that molecular mimicry between the two proteins causes antibodies to LAMP-2 in susceptible individuals after infection with fimbriated bacteria, and this in turn causes AAV (as illustrated in Figure 1). More data will be needed to confirm this novel hypothesis.

\section{Conclusion}

In summary, we have reviewed evidence that strongly supports the existence of genetic risk factors for AAV. As with other polygenic autoimmune diseases - for example, rheumatoid arthritis and SLE - AAV is likely to result from complex interactions between genetic variants and environmental triggers. Infection may trigger AAV, and we have outlined a number of possible mechanisms for this trigger. In particular, we have discussed a recently reported example of molecular mimicry which provides a new model for the pathogenesis of this autoimmune disease [90].

\section{Abbreviations}

AAV = ANCA-associated systemic vasculitis; $A N C A=$ anti-neutrophil cytoplasmic antibody; CANCA = cytoplasmic ANCA; Cl = confidence interval; CSS = Churg-Strauss syndrome; CTLA4 = cytotoxic T-lymphocyte antigen 4; ELISA = enzyme-linked immunosorbent assay; Fcy $\mathrm{R}=\mathrm{Fc}$ receptor; $\mathrm{IL}=$ interleukin; $\mathrm{MHC}=$ major histocompatibility complex; $\mathrm{MPA}=$ microscopic polyangiitis; $\mathrm{MPO}=$ myeloperoxidase; $\mathrm{OR}=$ odds ratio; $\mathrm{PANCA}=$ perinuclear ANCA; PR3 = proteinase $3 ;$ SLE = systemic lupus erythematosus; SNP = single nucleotide polymorphism; TNF = tumour necrosis factor; WG $=$ Wegener's granulomatosis.

\section{Acknowledgements}

Financial support was provided by the Wellcome Trust (Programme Grant Numbers 083650/Z/07/Z and 077092) and the NIHR Cambridge Biomedical Research Centre. The Cambridge Institute for Medical Research is in receipt of a Wellcome Trust Strategic Award (079895). LCW is a Medical Research Council Clinical Training Fellow, and KGCS is a Lister Prize Fellow. AJR is funded by an EU Marie Curie Excellence Chair (MEXC-CT-2006-042742).

\section{Author details}

${ }^{1}$ Cambridge Institute for Medical Research and Department of Medicine, University of Cambridge School of Clinical Medicine, Addenbrooke's Hospital, Hills Road, Cambridge CB2 OXY, UK

${ }^{2}$ Department of Pathology, Medical University of Vienna, Währinger Gürtel 18-20, 1090 Wien, Austria

${ }^{3}$ The Immunology Programme, Schools of Medicine and Medical Sciences, University of Aberdeen, Foresterhill, Aberdeen AB25 2ZD, UK

\section{Competing interests}

The authors declare that they have no competing interests.

Published: 15 February 2010

\section{References}

1. Hunder GG, Arend WP, Bloch DA, Calabrese LH, Fauci AS, Fries JF, Leavitt RY, Lie JT, Lightfoot RW Jr, Masi AT, McShane DJJ, Michel BA, Mills JA, Stevens MB, Wallace SL, Zvaifler NJ: The American College of Rheumatology 1990 criteria for the classification of vasculitis. Introduction. Arthritis Rheum 1990, 33:1065-1067.

2. Hagen EC, Daha MR, Hermans J, Andrassy K, Csernok E, Gaskin G, Lesavre P, Ludemann J, Rasmussen N, Sinico RA, Wiik A, van der Woude FJ: Diagnostic value of standardized assays for anti-neutrophil cytoplasmic antibodies in idiopathic systemic vasculitis. EC/BCR Project for ANCA Assay Standardization. Kidney Int 1998, 53:743-753.

3. Hoffman GS, Specks U: Antineutrophil cytoplasmic antibodies. Arthritis Rheum 1998, 41:1521-1537.

4. Lane SE, Watts RA, Shepstone L, Scott DG: Primary systemic vasculitis: clinical features and mortality. Q J Med 2005, 98:97-111.

5. Becker KG: The common variants/multiple disease hypothesis of common complex genetic disorders. Med Hypotheses 2004, 62:309-317.

6. Watts RA, Scott DG, Jayne DR, Ito-Ihara T, Muso E, Fujimoto S, Harabuchi Y, Kobayashi S, Suzuki K, Hashimoto H: Renal vasculitis in Japan and the UK - are there differences in epidemiology and clinical phenotype? Nephrol Dial Transplant 2008, 23:3928-3931.

7. Watts RA, Lane SE, Scott DG, Koldingsnes W, Nossent H, Gonzalez-Gay MA, Garcia-Porrua C, Bentham GA: Epidemiology of vasculitis in Europe. Ann Rheum Dis 2001, 60:1156-1157.

8. O'Donnell JL, Stevanovic VR, Frampton C, Stamp LK, Chapman PT: Wegener's granulomatosis in New Zealand: evidence for a latitude-dependent incidence gradient. Intern Med J 2007, 37:242-246.

9. Cotch MF, Hoffman GS, Yerg DE, Kaufman GI, Targonski P, Kaslow RA: The epidemiology of Wegener's granulomatosis. Estimates of the five-year period prevalence, annual mortality, and geographic disease distribution from population-based data sources. Arthritis Rheum 1996, 39:87-92.

10. Mahr A, Guillevin L, Poissonnet M, Ayme S: Prevalences of polyarteritis nodosa, microscopic polyangiitis, Wegener's granulomatosis, and ChurgStrauss syndrome in a French urban multiethnic population in 2000: a capture-recapture estimate. Arthritis Rheum 2004, 51:92-99.

11. Knight A, Sandin S, Askling J: Risks and relative risks of Wegener's granulomatosis among close relatives of patients with the disease. Arthritis Rheum 2008, 58:302-307.

12. Silman AJ, Hennessy E, Ollier B: Incidence of rheumatoid arthritis in a genetically predisposed population. Br J Rheumatol 1992, 31:365-368.

13. Jones MA, Silman AJ, Whiting S, Barrett EM, Symmons DP: Occurrence of rheumatoid arthritis is not increased in the first degree relatives of a population based inception cohort of inflammatory polyarthritis. Ann Rheum Dis 1996, 55:89-93.

14. Rottem M, Cotch MF, Fauci AS, Hoffman GS: Familial vasculitis: report of 2 families. J Rheumatol 1994, 21:561-563.

15. Manganelli P, Giacosa R, Fietta P, Zanetti A, Neri TM: Familial vasculitides: Churg-Strauss syndrome and Wegener's granulomatosis in 2 first-degree relatives. J Rheumatol 2003, 30:618-621.

16. Erlich H, Valdes AM, Noble J, Carlson JA, Varney M, Concannon P, Mychaleckyj JC, Todd JA, Bonella P, Fear AL, Lavant E, Louey A, Moonsamy P: HLA DR-DQ haplotypes and genotypes and type 1 diabetes risk: analysis of the type 1 diabetes genetics consortium families. Diabetes 2008, 57:1084-1092.

17. Rhodes B, Vyse TJ: The genetics of SLE: an update in the light of genomewide association studies. Rheumatology (Oxford) 2008, 47:1603-1611.

18. Cotch MF, Fauci AS, Hoffman GS: HLA typing in patients with Wegener granulomatosis. Ann Intern Med 1995, 122:635.

19. Spencer SJ, Burns A, Gaskin G, Pusey CD, Rees AJ: HLA class II specificities in vasculitis with antibodies to neutrophil cytoplasmic antigens. Kidney Int 1992, 41:1059-1063.

20. Papiha SS, Murty GE, Ad'Hia A, Mains BT, Venning M: Association of Wegener's granulomatosis with HLA antigens and other genetic markers. Ann Rheum Dis 1992, 51:246-248.

21. Jagiello P, Gencik M, Arning L, Wieczorek S, Kunstmann E, Csernok E, Gross $W L$, Epplen JT: New genomic region for Wegener's granulomatosis as revealed by an extended association screen with 202 apoptosis-related genes. Hum Genet 2004, 114:468-477.

22. Heckmann M, Holle JU, Arning L, Knaup S, Hellmich B, Nothnagel M, Jagiello P, Gross WL, Epplen JT, Wieczorek S: The Wegener's granulomatosis quantitative trait locus on chromosome 6 p21.3 as characterised by tagSNP genotyping. Ann Rheum Dis 2008, 67:972-979.

23. Stassen PM, Cohen-Tervaert JW, Lems SP, Hepkema BG, Kallenberg CG, Stegeman CA: HLA-DR4, DR13(6) and the ancestral haplotype A1B8DR3 are associated with ANCA-associated vasculitis and Wegener's granulomatosis. Rheumatology (Oxford) 2009, 48:622-625. 
24. Wieczorek S, Hellmich B, Gross WL, Epplen JT: Associations of Churg-Strauss syndrome with the HLA-DRB1 locus, and relationship to the genetics of antineutrophil cytoplasmic antibody-associated vasculitides: comment on the article by Vaglio et al. Arthritis Rheum 2008, 58:329-330.

25. Vaglio A, Martorana D, Maggiore U, Grasselli C, Zanetti A, Pesci A, Garini G, Manganelli P, Bottero P, Tumiati B, Sinico RA, Savi M, Buzio C, Neri TM: HLA-DRB4 as a genetic risk factor for Churg-Strauss syndrome. Arthritis Rheum 2007, 56:3159-3166

26. Witko-Sarsat V, Lesavre P, Lopez S, Bessou G, Hieblot C, Prum B, Noel LH, Guillevin L, Ravaud P, Sermet-Gaudelus I, Timsit J, Grunfeld JP, HalbwachsMecarelli L: A large subset of neutrophils expressing membrane proteinase 3 is a risk factor for vasculitis and rheumatoid arthritis. J Am Soc Nephrol 1999, 10:1224-1233.

27. Schreiber A, Busjahn A, Luft FC, Kettritz R: Membrane expression of proteinase 3 is genetically determined. J Am Soc Nephrol 2003, 14:68-75.

28. Rarok AA, Stegeman CA, Limburg PC, Kallenberg CG: Neutrophil membrane expression of proteinase 3 (PR3) is related to relapse in PR3-ANCAassociated vasculitis. J Am Soc Nephrol 2002, 13:2232-2238.

29. von Vietinghoff S, Busjahn A, Schonemann C, Massenkeil G, Otto B, Luft FC, Kettritz R: Major histocompatibility complex HLA region largely explains the genetic variance exercised on neutrophil membrane proteinase 3 expression. J Am Soc Nephrol 2006, 17:3185-3191.

30. Gencik M, Meller S, Borgmann S, Fricke H: Proteinase 3 gene polymorphisms and Wegener's granulomatosis. Kidney Int 2000, 58:2473-2477.

31. Morgan MD, Harper L, Williams J, Savage C: Anti-neutrophil cytoplasmassociated glomerulonephritis. J Am Soc Nephrol 2006, 17:1224-1234.

32. Griffith ME, Lovegrove JU, Gaskin G, Whitehouse DB, Pusey CD: $\mathrm{C}$-antineutrophil cytoplasmic antibody positivity in vasculitis patients is associated with the $\mathrm{Z}$ allele of alpha-1-antitrypsin, and P-antineutrophil cytoplasmic antibody positivity with the S allele. Nephrol Dial Transplant 1996, 11:438-443.

33. Savige JA, Chang L, Cook L, Burdon J, Daskalakis M, Doery J: Alpha 1 -antitrypsin deficiency and anti-proteinase 3 antibodies in antineutrophil cytoplasmic antibody (ANCA)-associated systemic vasculitis. Clin Exp Immunol 1995, 100:194-197.

34. Baslund B, Szpirt W, Eriksson S, Elzouki AN, Wiik A, Wieslander J, Petersen J: Complexes between proteinase 3 , alpha 1-antitrypsin and proteinase 3 anti-neutrophil cytoplasm autoantibodies: a comparison between alpha 1-antitrypsin PiZ allele carriers and non-carriers with Wegener's granulomatosis. Eur J Clin Invest 1996, 26:786-792.

35. Borgmann S, Endisch G, Urban S, Sitter T, Fricke H: A linkage disequilibrium between genes at the serine protease inhibitor gene cluster on chromosome 14q32.1 is associated with Wegener's granulomatosis. Clin Immunol 2001, 98:244-248.

36. Callea F, Gregorini G, Sinico A, Gonzales G, Bossolasco M, Salvidio G, Radice A, Tira P, Candiano G, Rossi G, Petti A, Ravera G, Ghiggeri G, Gusmano R: Alpha 1-antitrypsin (AAT) deficiency and ANCA-positive systemic vasculitis: genetic and clinical implications. Eur J Clin Invest 1997, 27:696-702.

37. Lhotta K, Vogel W, Meisl T, Buxbaum M, Neyer U, Sandholzer C, Konig P: Alpha 1 -antitrypsin phenotypes in patients with anti-neutrophil cytoplasmic antibody-positive vasculitis. Clin Sci (Lond) 1994, 87:693-695.

38. Audrain MA, Sesboue R, Baranger TA, Elliott J, Testa A, Martin JP, Lockwood CM, Esnault VL: Analysis of anti-neutrophil cytoplasmic antibodies (ANCA): frequency and specificity in a sample of 191 homozygous (PiZZ) alpha1antitrypsin-deficient subjects. Nephrol Dial Transplant 2001, 16:39-44.

39. Criswell LA, Pfeiffer KA, Lum RF, Gonzales B, Novitzke J, Kern M, Moser KL, Begovich AB, Carlton VE, Li W, Lee AT, Ortmann W, Behrens TW, Gregersen PK: Analysis of families in the multiple autoimmune disease genetics consortium (MADGC) collection: the PTPN22 620W allele associates with multiple autoimmune phenotypes. Am J Hum Genet 2005, 76:561-571.

40. Gregersen PK, Lee HS, Batliwalla F, Begovich AB: PTPN22: setting thresholds for autoimmunity. Semin Immunol 2006, 18:214-223.

41. Jagiello P, Aries P, Arning L, Wagenleiter SE, Csernok E, Hellmich B, Gross WL, Epplen JT: The PTPN22 620W allele is a risk factor for Wegener's granulomatosis. Arthritis Rheum 2005, 52:4039-4043.

42. Carr EJ, Clatworthy MR, Lowe CE, Todd JA, Wong A, Vyse TJ, Kamesh L, Watts RA, Lyons PA, Smith KG: Contrasting genetic association of IL2RA with SLE and ANCA- associated vasculitis. BMC Med Genet 2009, 10:22.

43. Carr EJ, Niederer HA, Williams J, Harper L, Watts RA, Lyons PA, Smith KGC: Confirmation of the genetic association of CTLA4 and PTPN22 with ANCAassociated vasculitis. BMC Med Genet 2009, 10:121.
44. Steiner K, Moosig F, Csernok E, Selleng K, Gross WL, Fleischer B, Broker BM: Increased expression of CTLA-4 (CD152) by T and B lymphocytes in Wegener's granulomatosis. Clin Exp Immunol 2001, 126:143-150.

45. Brand O, Gough S, Heward J: HLA, CTLA-4 and PTPN22: the shared genetic master-key to autoimmunity? Expert Rev Mol Med 2005, 7:1-15.

46. Giscombe R, Wang X, Huang D, Lefvert AK: Coding sequence 1 and promoter single nucleotide polymorphisms in the CTLA-4 gene in Wegener's granulomatosis. J Rheumatol 2002, 29:950-953.

47. Wang XB, Zhao X, Giscombe R, Lefvert AK: A CTLA-4 gene polymorphism at position -318 in the promoter region affects the expression of protein. Genes Immun 2002, 3:233-234.

48. Slot MC, Sokolowska MG, Savelkouls KG, Janssen RG, Damoiseaux JG, Cohen Tervaert JW: Immunoregulatory gene polymorphisms are associated with ANCA-related vasculitis. Clin Immunol 2008, 128:39-45.

49. Duffy DL: Genetic determinants of diabetes are similarly associated with other immune-mediated diseases. Curr Opin Allergy Clin Immunol 2007, 7:468-474.

50. Schmitt WH, Heesen C, Csernok E, Rautmann A, Gross WL: Elevated serum levels of soluble interleukin-2 receptor in patients with Wegener's granulomatosis. Association with disease activity. Arthritis Rheum 1992, 35:1088-1096.

51. Zhou Y, Giscombe R, Huang D, Lefvert AK: Novel genetic association of Wegener's granulomatosis with the interleukin 10 gene. J Rheumato/ 2002, 29:317-320.

52. Bartfai Z, Gaede Kl, Russell KA, Murakozy G, Muller-Quernheim J, Specks U: Different gender-associated genotype risks of Wegener's granulomatosis and microscopic polyangiitis. Clin Immunol 2003, 109:330-337.

53. Wieczorek S, Hellmich B, Arning L, Moosig F, Lamprecht P, Gross WL, Epplen $J T$ : Functionally relevant variations of the interleukin- 10 gene associated with antineutrophil cytoplasmic antibody-negative Churg-Strauss syndrome, but not with Wegener's granulomatosis. Arthritis Rheum 2008, 58:1839-1848.

54. Mamegano K, Kuroki K, Miyashita R, Kusaoi M, Kobayashi S, Matsuta K, Maenaka K, Colonna M, Ozaki S, Hashimoto H, Takasaki Y, Tokunaga K, Tsuchiya N: Association of LILRA2 (ILT1, LIR7) splice site polymorphism with systemic lupus erythematosus and microscopic polyangiitis. Genes Immun 2008, 9:214-223.

55. Gilfillan S, Chan CJ, Cella M, Haynes NM, Rapaport AS, Boles KS, Andrews DM, Smyth MJ, Colonna M: DNAM-1 promotes activation of cytotoxic lymphocytes by nonprofessional antigen-presenting cells and tumors. J Exp Med 2008, 205:2965-2973.

56. Wieczorek S, Hoffjan S, Chan A, Rey L, Harper L, Fricke H, Holle JU, Gross WL, Epplen JT, Lamprecht P: Novel association of the CD226 (DNAM-1) Gly307Ser polymorphism in Wegener's granulomatosis and confirmation for multiple sclerosis in German patients. Genes Immun 2009, 10:591-595.

57. Gencik M, Meller S, Borgmann S, Sitter T, Menezes Saecker AM, Fricke H, Epplen JT: The association of CD18 alleles with anti-myeloperoxidase subtypes of ANCA-associated systemic vasculitides. Clin Immuno/ 2000, 94:9-12.

58. Persson U, Truedsson L, Westman KW, Segelmark M: C3 and C4 allotypes in anti-neutrophil cytoplasmic autoantibody (ANCA)-positive vasculitis. Clin Exp Immunol 1999, 116:379-382.

59. Huang D, Giscombe R, Zhou Y, Lefvert AK: Polymorphisms in CTLA-4 but not tumor necrosis factor-a or interleukin $1 \beta$ genes are associated with Wegener's granulomatosis. J Rheumatol 2000, 27:397-401

60. Zhou Y, Huang D, Paris PL, Sauter CS, Prock KA, Hoffman GS: An analysis of CTLA-4 and proinflammatory cytokine genes in Wegener's granulomatosis. Arthritis Rheum 2004, 50:2645-2650.

61. Kocher M, Edberg JC, Fleit HB, Kimberly RP: Antineutrophil cytoplasmic antibodies preferentially engage Fc gammaRIllb on human neutrophils. J Immunol 1998, 161:6909-6914.

62. Jayne DR, Weetman AP, Lockwood CM: IgG subclass distribution of autoantibodies to neutrophil cytoplasmic antigens in systemic vasculitis. Clin Exp Immunol 1991, 84:476-481.

63. Mulder AH, Heeringa P, Brouwer E, Limburg PC, Kallenberg CG: Activation of granulocytes by anti-neutrophil cytoplasmic antibodies (ANCA): a FC gamma RII-dependent process. Clin Exp Immunol 1994, 98:270-278.

64. Dijstelbloem HM, Scheepers RH, Oost WW, Stegeman CA, van der Pol WL, Sluiter WJ, Kallenberg CG, van de Winkel JG, Tervaert JW: Fcy receptor polymorphisms in Wegener's granulomatosis: risk factors for disease relapse. Arthritis Rheum 1999, 42:1823-1827. 
65. van der Pol W, van de Winkel JG: IgG receptor polymorphisms: risk factors for disease. Immunogenetics 1998, 48:222-232.

66. Stegeman CA, Tervaert JW, Sluiter WJ, Manson WL, de Jong PE, Kallenberg CG: Association of chronic nasal carriage of Staphylococcus aureus and higher relapse rates in Wegener granulomatosis. Ann Intern Med 1994, 120:12-17.

67. Tse WY, Abadeh S, McTiernan A, Jefferis R, Savage CO, Adu D: No association between neutrophil FcyRlla allelic polymorphism and anti-neutrophil cytoplasmic antibody (ANCA)-positive systemic vasculitis. Clin Exp Immunol 1999, 117:198-205.

68. Tse WY, Abadeh S, Jefferis R, Savage CO, Adu D: Neutrophil FcyRIIllb allelic polymorphism in anti-neutrophil cytoplasmic antibody (ANCA)-positive systemic vasculitis. Clin Exp Immunol 2000, 119:574-577.

69. McCarroll SA, Kuruvilla FG, Korn JM, Cawley S, Nemesh J, Wysoker A, Shapero MH, de Bakker PI, Maller JB, Kirby A, Elliott AL, Parkin M, Hubbell E, Webster T, Mei R, Veitch J, Collins PJ, Handsaker R, Lincoln S, Nizzari M, Blume J, Jones KW, Rava R, Daly MJ, Gabriel SB, Altshuler D: Integrated detection and population-genetic analysis of SNPs and copy number variation. Nat Genet 2008, 40:1166-1174.

70. Mamtani M, Rovin B, Brey R, Camargo JF, Kulkarni H, Herrera M, Correa P, Holliday S, Anaya JM, Ahuja SK: CCL3L1 gene-containing segmental duplications and polymorphisms in CCR5 affect risk of systemic lupus erythaematosus. Ann Rheum Dis 2008, 67:1076-1083.

71. McKinney C, Merriman ME, Chapman PT, Gow PJ, Harrison AA, Highton J, Jones PB, MCLean L, O'Donnell JL, Pokorny V, Spellerberg M, Stamp LK, Willis J, Steer S, Merriman TR: Evidence for an influence of chemokine ligand 3-like 1 (CCL3L1) gene copy number on susceptibility to rheumatoid arthritis. Ann Rheum Dis 2008, 67:409-413.

72. Yang Y, Chung EK, Wu YL, Savelli SL, Nagaraja HN, Zhou B, Hebert M, Jones KN, Shu Y, Kitzmiller K, Blanchong, CA, McBride KL, Higgins GC, Rennebohm RM, Rice, RR, Hackshaw KV, Roubey RA, Grossman JM, Tsao BP, Birmingham DJ, Rovin BH, Hebert LA, Yu CY: Gene copy-number variation and associated polymorphisms of complement component $\mathrm{C} 4$ in human systemic lupus erythematosus (SLE): low copy number is a risk factor for and high copy number is a protective factor against SLE susceptibility in European Americans. Am J Hum Genet 2007, 80:1037-1054.

73. Fanciulli M, Norsworthy PJ, Petretto E, Dong R, Harper L, Kamesh L, Heward JM, Gough SC, de Smith A, Blakemore Al, Froguel P, Owen CJ, Pearce SH, Teixeira L, Guillevin L, Graham DS, Pusey CD, Cook HT, Vyse TJ, Aitman TJ: FCGR3B copy number variation is associated with susceptibility to systemic, but not organ-specific, autoimmunity. Nat Genet 2007, 39:721-723.

74. Willcocks LC, Lyons PA, Clatworthy MR, Robinson Jl, Yang W, Newland SA, Plagnol V, McGovern NN, Condliffe AM, Chilvers ER, Adu D, Jolly EC, Watts R, Lau YL, Morgan AW, Nash G, Smith KGC: Copy number of FCGR3B, which is associated with systemic lupus erythematosus, correlates with protein expression and immune complex uptake. J Exp Med 2008, 205:1573-1582.

75. McCarroll SA, Altshuler DM: Copy-number variation and association studies of human disease. Nat Genet 2007, 39:S37-S42.

76. Hollox EJ, Detering JC, Dehnugara T: An integrated approach for measuring copy number variation at the FCGR3 (CD16) locus. Hum Mutat 2009, 30:477-484.

77. Hampe J, Franke A, Rosenstiel P, Till A, Teuber M, Huse K, Albrecht M, Mayr G, De La Vega FM, Briggs J, Gunther S, Prescott NJ, Onnie CM, Hasler R, Sipos B, Folsch UR, Lengauer T, Platzer M, Mathew CG, Krawczak M, Schreiber S: A genome-wide association scan of nonsynonymous SNPs identifies a susceptibility variant for Crohn disease in ATG16L1. Nat Genet 2007, 39:207-211.

78. Mahr AD, Neogi T, Merkel PA: Epidemiology of Wegener's granulomatosis: lessons from descriptive studies and analyses of genetic and environmental risk determinants. Clin Exp Rheumatol 2006, 24:S82-S91.

79. Hogan SL, Cooper GS, Savitz DA, Nylander-French LA, Parks CG, Chin H, Jennette CE, Lionaki S, Jennette JC, Falk RJ: Association of silica exposure with anti-neutrophil cytoplasmic autoantibody small-vessel vasculitis: a population-based, case-control study. Clin J Am Soc Nephrol 2007, 2:290-299.

80. Aikoh T, Tomokuni A, Matsukii T, Hyodoh F, Ueki H, Otsuki T, Ueki A: Activation-induced cell death in human peripheral blood lymphocytes after stimulation with silicate in vitro. Int J Oncol 1998, 12:1355-1359.

81. de Lind van Wijngaarden RA, van Rijn L, Hagen EC, Watts RA, Gregorini G, Tervaert JW, Mahr AD, Niles JL, de Heer E, Bruijn JA, Bajema IM: Hypotheses on the etiology of antineutrophil cytoplasmic autoantibody associated vasculitis: the cause is hidden, but the result is known. Clin J Am Soc Nephrol 2008, 3:237-252.

82. Short AK, Lockwood CM: Antigen specificity in hydralazine associated ANCA positive systemic vasculitis. Q J Med 1995, 88:775-783.

83. Mathieson PW, Peat DS, Short A, Watts RA: Coexistent membranous nephropathy and ANCA-positive crescentic glomerulonephritis in association with penicillamine. Nephrol Dial Transplant 1996, 11:863-866.

84. Stegeman CA, Tervaert JW, de Jong PE, Kallenberg CG: Trimethoprimsulfamethoxazole (co-trimoxazole) for the prevention of relapses of Wegener's granulomatosis. Dutch Co-Trimoxazole Wegener Study Group. NEngl J Med 1996, 335:16-20.

85. Chirinos JA, Corrales-Medina VF, Garcia S, Lichtstein DM, Bisno AL, Chakko S: Endocarditis associated with antineutrophil cytoplasmic antibodies: a case report and review of the literature. Clin Rheumato/ 2007, 26:590-595.

86. Miranda-Filloy JA, Veiga JA, Juarez Y, Gonzalez-Juanatey C, Gonzalez-Gay MA, Garcia-Porrua C: Microscopic polyangiitis following recurrent Staphylococcus aureus bacteremia and infectious endocarditis. Clin Exp Rheumatol 2006, 24:705-706.

87. Hellmich B, Ehren M, Lindstaedt M, Meyer M, Pfohl M, Schatz H: Anti-MPOANCA-positive microscopic polyangiitis following subacute bacterial endocarditis. Clin Rheumatol 2001, 20:441-443.

88. Oldstone MB: Molecular mimicry, microbial infection, and autoimmune disease: evolution of the concept. Curr Top Microbiol Immuno/ 2005, 296:1-17.

89. Fourneau JM, Bach JM, van Endert PM, Bach JF: The elusive case for a role of mimicry in autoimmune diseases. Mol Immunol 2004, 40:1095-1102.

90. Kain R, Exner M, Brandes R, Ziebermayr R, Cunningham D, Alderson CA, Davidovits A, Raab I, Jahn R, Ashour O, Spitzauer S, Sunder-Plassmann G. Fukuda M, Klemm P, Rees AJ, Kerjaschki D: Molecular mimicry in pauciimmune focal necrotizing glomerulonephritis. Nat Med 2008, 14:1088-1096.

91. Pendergraft WF, 3rd, Preston GA, Shah RR, Tropsha A, Carter CW, Jr, Jennette JC, Falk RJ: Autoimmunity is triggered by CPR-3(105-201), a protein complementary to human autoantigen proteinase-3. Nat Med 2004, 10:72-79.

92. Savige J, Nassis L, Cooper T, Paspaliaris B, Martinello P, MacGregor D: Antineutrophil cytoplasmic antibody (ANCA)-associated systemic vasculitis after immunisation with bacterial proteins. Clin Exp Rheumatol 2002, 20:783-789.

93. Eskelinen EL: Roles of LAMP-1 and LAMP-2 in lysosome biogenesis and autophagy. Mol Aspects Med 2006, 27:495-502.

94. Gough NR, Fambrough DM: Different steady state subcellular distributions of the three splice variants of lysosome-associated membrane protein LAMP-2 are determined largely by the $\mathrm{COOH}$-terminal amino acid residue. J Cell Biol 1997, 137:1161-1169.

95. Elzouki AN, Segelmark M, Wieslander J, Eriksson S: Strong link between the alpha 1-antitrypsin PiZ allele and Wegener's granulomatosis. J Intern Med 1994, 236:543-548

\section{doi:10.1186/ar2928}

Cite this article as: Willcocks $L C$, et al:: The contribution of genetic variation and infection to the pathogenesis of ANCA-associated systemic vasculitis. Arthritis Research \& Therapy 2010, 12:202. 